Indonesian Science Education Research
(ISER)

\title{
THE EFFECT OF THE PROBLEM BASED LEARNING (PBL) MODEL WITH POLYA TECHNIQUES ON STUDENTS 'COGNITIVE LEARNING OUTCOMES IN BASIC BUSINESS AND ENERGY MATERIALS IN CLASS X SEMESTER II SENIOR HIGH SCHOOL 1 BATANG KUIS
}

\author{
${ }^{\mathbf{1}}$ Yola Heldianty dan ${ }^{\mathbf{1}}$ Togi Tampubolon \\ ${ }^{1}$ Department of Physic Education Faculty of Mathematics and Science Universitas Negeri Medan, \\ Indonesia \\ heldiantyy@gmail.com
}

Accepted: September $5^{\text {th }}, 2020$. Published: October $6^{\text {th }}, 2020$

\begin{abstract}
This study aims to determine the effect of the problem based learning (PBL) model with the POLYA technique on students' cognitive learning outcomes on the subject matter of business and energy in class X semester II Senior High School Negeri 1 Batang Kuis in 2018/2019 Academic years. This type of research was a quasi experiment with a two group pretestposttest design. The population of all students of class X Senior High School Negeri 1 Batang Kuis which consists of five classes. The sample selection was done by using cluster random sampling technique. The study involved two classes, namely the experimental class and the control class who were given different treatments. The experimental class and control class each consisted of 30 students. The experimental class was treated with the problem based learning (PBL) model with the POLYA technique and the control class was treated with the conventional learning model. The instrument used in this study was a cognitive learning outcome test in the form of a problem with a total of 8 questions with POLYA's technique scoring guidelines and student activity sheets. The data in this study were analyzed using hypothesis testing t-test. The results showed that there were significant differences, so it can be concluded that there was an effect of using the problem based learning (PBL) model with the POLYA technique on students' cognitive learning outcomes on the subject matter of business and energy in class X Semester II Senior High School Negeri 1 Batang Kuis.
\end{abstract}

Keywords: problem based learning (PBL), POLYA technique, cognitive learning outcomes 


\section{Introduction}

One of the problems facing the world of education in Indonesia today is the weak learning process. The learning process that occurs in the classroom is directed at students' ability to memorize information only. As a result, education in Indonesia is not directed at forming intelligent people, having the ability to solve life problems, and is not directed at forming creative and innovative people (Sudarman, 2010).

The facts above are reinforced by the results of the Program for International Student Assessment in 2015 which was released in December 2016, a program initiated by the Organization for Economic Co-operation and Development (OECD) states Indonesia's ranking for science 62, mathematics 63, and reads 64 of 70 countries. The average score for PISA 2015 is science score 403, Mathematics 375, and reading 397, looking at the results in 2012, PISA 2015 results have increased, it's just that the ability of Indonesian children aged 15 years under this program is still considered low compared to children other in the world, because the average PISA scores, respectively, are 494, 496, and 501 (OECD, 2016).

Basically, physics is the scope of science and will certainly be the focus of studies regarding the low quality of science learning in Indonesia. Physics subjects are generally felt to be difficult by students because physics requires students to understand the concepts in the physics learning process and most students have not been able to connect the material being studied with the knowledge used. In addition, physics teachers only use conventional learning models in the form of lecturing, question and answer activities, taking notes and working on questions so that students receive abstract knowledge without experiencing it themselves. As a result, physics learning is only oriented to memorization and formulas without understanding the concepts of physics itself.

The same problem also occurs in Senior High School Negeri 1 Batang Kuis which will be used as the research population. From the results of the questionnaire given, it was obtained that
13\% (4 people) of students did not like physics because they thought physics was not interesting, very complicated and difficult to understand because there were too many physics formulas to memorize, $81 \%$ (25 people) among them stated that physics lessons are normal because they think physics lessons are too monotonous and uninteresting and 6\% (2 people) students like physics because they think physics is challenging. This data shows that physics is an unwelcome subject so it is not surprising that the learning outcomes obtained are still low.

Based on the above problems, a learning model and technique is needed that can attract students to want to study physics and make students understand the concepts of physics. As stated by Yamin (2010), learning is a process where people acquire skills, skills and attitudes. So, a learning model must be applied that is able to invite students to really learn and get really good learning outcomes. These models and techniques must also be adapted to the learning objectives and subject matter being taught.

Permendikbud No. 103 of 2014 states that, the PBL model is one of the main learning models in the 2013 curriculum which is expected to shape scientific behavior, social behavior and develop students' curiosity. This is reinforced by the results of research by Aziz and Rokhmat (2015) which showed that there was an effect of problem-based learning models with experimental methods on the physics learning outcomes of class $\mathrm{X}$ students of Senior High School 1 Gunungsari, West Lombok district, 2014/2015 academic year.

According to Arends (2008), the problem-based learning model is a learning model that presents students with authentic and meaningful problematic situations, which can serve as a stepping stone for investigation and investigation. Problembased learning model is a learning model that involves students to solve a problem through the stages of the scientific method so that students can learn knowledge related to the problem as well as have the skills to solve problems. In line with Trianto's (2009) opinion, the problem based learning (PBL) model is an effective learning model for 
teaching higher order thinking processes. This learning helps students to process information already in their minds and organize their own knowledge about the social world and its surroundings.

This research does not only apply the PBL model, but also applies the POLYA technique. The POLYA technique itself in this study acts to assist students in solving problem-based problems. According to POLYA in (Selcuk, 2008) the solution to problem solving contains 4 stages of completion, namely: (1) understanding of the problem (see); (2) completion planning (plan); (3) carry out problem solving planning (do); and (4) rechecking the settlement (check).

The same research has been conducted previously by Tanjung (2016) with the title implementation of problembased learning model of POLYA technique on student learning outcomes and activities on the subject matter of mathematical physics and received a positive response from unimed physics students class of 2014/2015. The results of his research concluded that there was an influence from the problem-based learning model with the POLYA technique on the learning outcomes and activities of the 2014/2015 class of physics study program students.

\section{Research Method}

This research was conducted at Senior High School Negeri 1 Batang Kuis even semester of the 2018/2019 academic year. The population in this study were all students of class $\mathrm{X}$ MIA academic year $2018 / 2019$. The sample in this study consisted of two classes, namely class $\mathrm{X}$ MIA-3 as the control class, and class $\mathrm{X}$ MIA-2 as the experimental class, each of which amounted to 30 people. The experimental class and control class were taken by using cluster random sampling technique, namely the sampling technique from the population which was done randomly.

This study involved two classes, namely the experimental class and the control class who were given different treatments. The problem based learning model uses the POLYA technique in the experimental class, while the control class uses conventional learning. The design of this study was a two group pretest - posttest which can be seen in Table 1 .

Table 1.Two Group Pretest - Posttest Design

\begin{tabular}{llll}
\hline Kelas & Pretest & Treat & Postest \\
\hline Experiment & $\mathrm{T}_{1}$ & $\mathrm{X}$ & $\mathrm{T}_{2}$ \\
\hline Control & $\mathrm{T}_{1}$ & $\mathrm{Y}$ & $\mathrm{T}_{2}$ \\
\hline
\end{tabular}

Information:

$\mathrm{T}_{1} \quad=$ initial ability test (pretest)

$\mathrm{T}_{2} \quad=$ final ability test (posttest)

$\mathrm{X}=$ treatment in the experimental class, namely the application of the problem based learning model with the POLYA technique

$\mathrm{Y} \quad=$ treatment in the control class, namely the application of conventional learning

The researcher gave a pretest to the experimental class and the control class. The instrument used in the study was a cognitive learning outcome test, a problem cognitive learning outcome test consisting of 8 essay questions. The cognitive learning outcomes test in the form of problems first standardized using the content validity test by two lecturers and one teacher according to the expert experts. After the pretest data were obtained, data analysis was carried out using the normality test, namely the Lilliefors test, homogeneity test and variance equality test. After that, the twoparty t-test hypothesis testing was conducted to determine the students' initial abilities in the two sample groups, in this case the initial abilities of the two samples must be the same. Furthermore, the researcher taught the subject matter using the PBL model with the POLYA technique in the experimental class and conventional learning in the control class. The difference in the final results can be seen by posttesting using the $t$ test to determine the effect of problem based learning (PBL) treatment with the POLYA technique on student cognitive learning outcomes. 


\section{Result and Discussion}

\section{a. Result}

The data described in this study include data on student cognitive learning outcomes on business and energy materials, which are given different treatments, namely 1) problem-based learning (PBL) models with POLYA technique, 2) learning using conventional learning. The results of the pretest data for the experimental class and control class students can be shown in Figure 1.

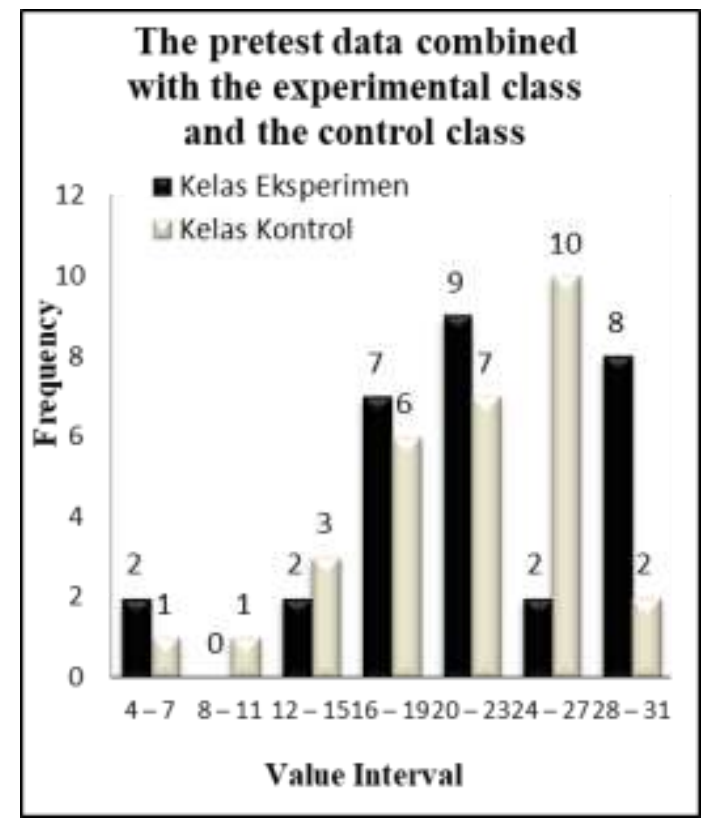

Figure 1. Bar chart of students' pretest scores

The picture above shows that the pretest scores in the experimental class and the control class have low scores, but the comparison of the average pretest scores for the experimental class and control class is not much different, namely 21.39 and 20.59 .

The frequency distribution of posttest data for students in the experimental and control classes can be visualized in Figure 2.

Figure 2 shows that the posttest score of the experimental class is higher than the posttest score of the control class, the comparison of the mean scores is 75.56 and 68.58. There is an increase in learning outcomes obtained in both classes, it can be concluded that the cognitive learning outcomes of the experimental class students are better than the cognitive learning outcomes of the control class students.

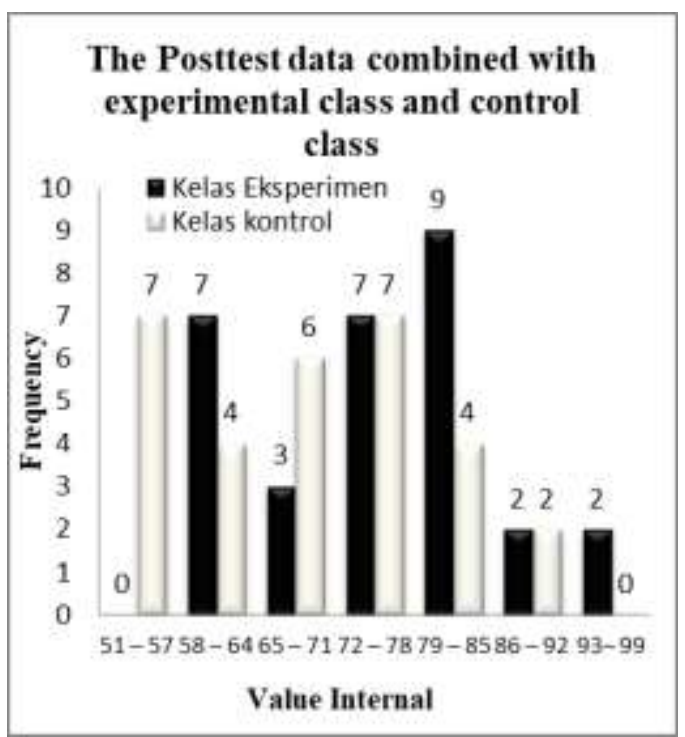

Figure 2. Bar chart of students' post-test scores

The data described in this study include learning outcomes and students' problem solving abilities in the subject of Elasticity and Hooke's Law, which are given different treatments, namely 1) inquiry training learning model with multiple representations, 2) conventional learning models. The results of the pretest data for the experimental class and control class students for learning outcomes can be seen in Table 2.

The results showed that the increase in student cognitive learning outcomes was supported by student activity during the learning process. The activities observed in this study were students' ability to orientate problems, organization in learning, group investigations, present work and evaluate the problem-solving process. The relationship between learning outcomes and student activities is shown from the increase in the average value of student activity in the experimental class at each meeting with the average value at the first meeting which is 54 , the second meeting is 79 and at the third meeting is 93 so that the average value of student activity during three meetings, namely 75 . The average value of the experimental class students' activities is visualized by the bar chart in Figure 3. 


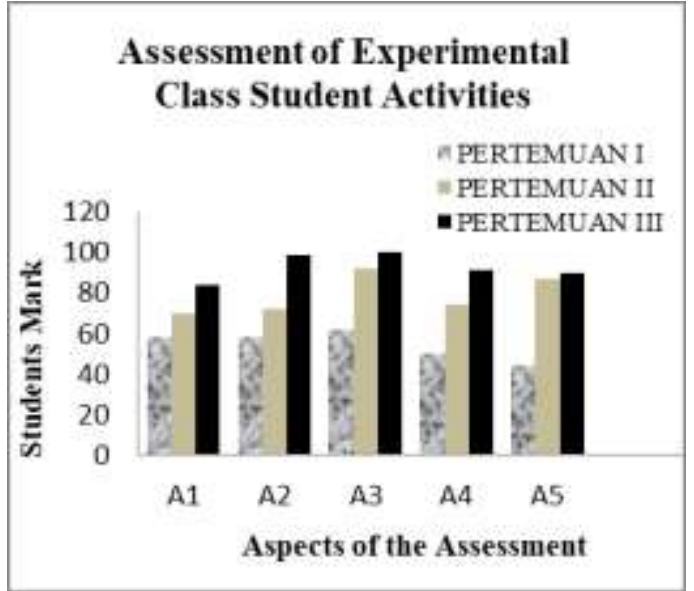

Figure 3. Bar chart of the experimental class student activity scores

Information:

A1: Orientation to the problem

A2: Organization in learning

A3: Group investigation

A4: Presenting the work

A5: Evaluating the problem-solving process

\section{b. Disscusion}

Based on the research data, it can be seen that the experimental class which was taught using the problem based learning (PBL) model with the POLYA technique resulted in an average pretest score of 21.39 and an average post-test score of 75.56 while the control class was taught using In conventional learning, the average pretest score was 20.59 and the post-test average score was 68.58 . The results showed that the average value of the experimental class treated by applying the problem based learning (PBL) model with the POLYA technique was higher than the control class with conventional learning.

Based on the normality and homogeneity test of the pretest and posttest data, it can be concluded that the research data has met the test requirements for testing the research hypothesis. From the results of hypothesis testing on post-test data, it is obtained that $t_{\text {count }}>t_{\text {table }}$ means that $\mathrm{Ha}$ is accepted and $\mathrm{H}_{0}$ is rejected, so it can be concluded that there is an effect of the problem-based learning model with its POLYA technique on students' cognitive learning outcomes.

The difference in cognitive learning outcomes of the two classes can be explained by the theory that basically the problem-based learning model is a learning model that provides problems in the classroom, and the problem solving technique is carried out using the fourindicator pattern technique (Selcuk, 2008), namely: 1) understanding the problem, 2) problem solving planning, 3) problem solving, 4) re-checking problem solving so that it makes it easier for students to solve problem-based problems given by the teacher. After the problem is solved, students conduct a discussion in class to convey the results of solving the problems that have been found.

Conventional learning has not been able to encourage students to carry out direct investigations and exercises to find solutions to the problems given. Conventional learning only focuses students on receiving the material presented by the teacher in front of the class so that students become passive and learning outcomes are less than optimal.

The acquisition of higher cognitive learning outcomes in the experimental class was also supported by the acquisition of student activity observations for 5 aspects of observation which showed better results than the control class. This difference in results occurs because in the experimental class students are trained to work together in solving problems by applying the four POLYA steps, making it easier for students to complete the given test. The experimental class also provides opportunities for students to explore, collect and analyze data to solve problems so that students are able to think critically, logically, analytically and systematically.

This was because the problem-based learning model with the POLYA technique involves all students to be active in the class in collaboration and finding solutions to the problems that are being studied through question and answer activities and group discussions. The problems presented are proven through experimental activities that require each student in the group to participate. Each group of students expressed their opinion about the solution to the problem presented then discussed to find the most appropriate solution. Then each group presents the results of their discussion 
in front of the class. The active involvement of all students during the learning process is what can improve student learning outcomes, especially cognitive learning outcomes.

This is in line with the research of Yul Ifda Tanjung (2016), who concluded that there is an effect of the problem-based learning model with his POLYA technique on student learning outcomes and activities in the physics-mathematics course II physics education study program class of 2014/2015. In addition, Rudtin (2013) concludes that learning by applying POLYA's steps in the problem-based instruction model can improve students' problem-solving abilities and help students be more focused in solving rectangular story problems in grade VII students of SMP Negeri 7 Palu.

The problem-based learning (PBL) model with the POLYA technique has made learning outcomes better than conventional learning, but there are several obstacles in conducting research, namely 1) Researchers have not maximally managed time so all syntax is less effective when implementing the learning process 2 ) The difficulty of determining the problems in the student worksheet that will be solved by students during the learning process. The presentation of the problem is very important in applying the problem-based learning model. Researcher's limitations in determining problems that cause research results are not optimal.

\section{Conclusion}

Based on the research results obtained from the results of data analysis and hypothesis testing, it can be concluded as follows:

Student learning activities on the subject matter of business and energy using the PBL model with the POLYA technique in class X Senior High School Negeri 1 Batang Kuis in 2018/2019 academic year was in the active category.

Based on the results of hypothesis testing with one-party t-test, it was found that there was an effect of the Problem Based Learning model with the POLYA technique on students' cognitive learning outcomes on business and energy materials in class X semester II Senior High School Negeri 1 Batang Kuis Academic year 2018/2019.

Based on the results of the research conducted, it was found that there was a difference which was a significant influence of the inquiry training learning model with multiple representations on student learning outcomes and problem-solving abilities on the subject of Elasticity and Hooke's Law in class XI Senior High School 17 Medan.

\section{Suggestion}

Based on the discussion of the research results, several things are suggested as follows:

When doing research, the constraint experienced by researchers was that time was not well organized. Therefore, for future researchers, it is suggested to be smarter in optimizing time so that all syntax can be carried out properly and students get better learning outcomes.

At the time of conducting research, the constraints experienced by researchers were students who were less enthusiastic because they had not been trained in how to work the Problem Based Learning model with the POLYA technique. Therefore, it is recommended for further researchers to do exercises before using the Problem Based Learning model with the POLYA technique for students, so that students better understand and are trained in how the learning model will be delivered, so that the learning process runs smoothly.

\section{Reference}

Arends, R.I., (2008), Learning To Teach, Pustaka Pelajar, Yogyakarta.

Aziz \& Rokhmat., (2015), Pengaruh Model Pembelajaran Berbasis Masalah dengan Metode Eksperimen Terhadap Hasil Belajar Fisika Siswa Kelas $\quad \mathrm{X}$ SMAN 1 Gunungsari Kabupaten Lombok Barat Tahun Pelajaran 2014/2015, Jurnal 
Pendidikan Fisika dan Teknologi, 1 (3) : 103-108.

Selcuk, S, G., Caliskan, S., \& Erol, M., (2008), The Effects of Problem Solving Instruction on Physics Achievement, Problem Solving Performance and Strategy Use. Lat. Am. J. Phys. Educ, 2 (3) : 151-166.

Rudtin, N. A., (2013), Penerapan Langkah POLYA dalam Model PBI untuk Meningkatkan Kemampuan Siswa Menyelesaikan Soal Cerita Persegi Panjang, Jurnal Elektronik Pendidikan Matematika Tadulako, 1 (1) : 17-31.

OECD., (2016), Indonesia - OECD Data, https://data.oecd.org/indonesia.htm 1 (diakses Januari 2019).

Sudarman., (2010), Problem Based Learning : Suatu Model untuk Mengembangkan dan Meningkatkan Kemampuan Memecahkan Masalah, Jurnal Pendidikan Inovatif, 2 (2) : 68-73.

Tanjung, Y.I., (2016), Implementasi Model Pembelajaran Berbasis Masalah dengan Teknik POLYA Terhadap Hasil Belajar Fisika Matematika. Jurnal IKALFI, 2 (2):1-5.

Trianto., (2009), Mendesain Model Pembelajaran InovatifProgresif:Konsep, Landasan dan implementasinya pada Kurikulum Tingkat Satuan Pendidikan, Penerbit Kencana, Jakarta.

Undang-Undang RI Nomor 20 Tahun 2003 pasal 3 Tentang Sistem Pendidikan Nasional, luk.staff.ugm.ac.id-UU20-
2003Sisdiknas (Diakses pada tanggal 2 Januari 2019).

Yamin, (2010), Strategi Pembelajaran Berbasis Kompetensi, Gaung Persada Press, Jakarta. 